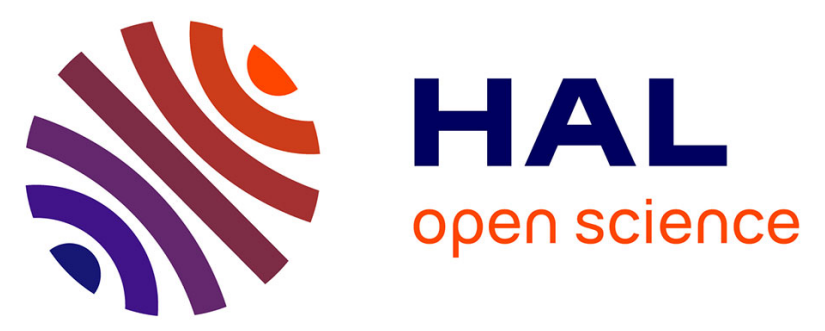

\title{
Microbial mat development and dolomite formation under pre-evaporitic conditions during the Atlantic in a temperate area: The Sarliève Lake (French Massif Central)
}

Jean-Robert Disnar, Maya Stefanova, Jean-Gabriel Bréhéret, Jean-Jacques

\author{
Macaire
}

\section{To cite this version:}

Jean-Robert Disnar, Maya Stefanova, Jean-Gabriel Bréhéret, Jean-Jacques Macaire. Microbial mat development and dolomite formation under pre-evaporitic conditions during the Atlantic in a temperate area: The Sarliève Lake (French Massif Central). Organic Geochemistry, 2011, 42 (9), pp.10891098. 10.1016/j.orggeochem.2011.06.015 . insu-00616301

\section{HAL Id: insu-00616301 https://hal-insu.archives-ouvertes.fr/insu-00616301}

Submitted on 31 Aug 2011

HAL is a multi-disciplinary open access archive for the deposit and dissemination of scientific research documents, whether they are published or not. The documents may come from teaching and research institutions in France or abroad, or from public or private research centers.
L'archive ouverte pluridisciplinaire HAL, est destinée au dépôt et à la diffusion de documents scientifiques de niveau recherche, publiés ou non, émanant des établissements d'enseignement et de recherche français ou étrangers, des laboratoires publics ou privés. 
Microbial mat development and dolomite formation under pre-evaporitic conditions during the Atlantic in a temperate area: the Sarliève Lake (French Massif Central)

Jean-Robert Disnar $^{a^{*}}$, Maya Stefanova ${ }^{\mathrm{a}, \mathrm{b}}$, Jean-Gabriel Bréheret $^{\mathrm{c}}$, Jean-Jacques Macaire ${ }^{\mathrm{c}}$

a Université d'Orléans, CNRS/INSU UMR 6113 ISTO, 1A, rue de la Férollerie, 45071 Orléans cedex 2, France

${ }^{\mathrm{b}}$ Institute of Organic Chemistry, Bulgarian Academy of Sciences, Sofia 1113, Bulgaria

${ }^{\mathrm{c}}$ Université François-Rabelais de Tours, CNRS/INSU UMR 6113 ISTO, Faculté des Sciences et Techniques, Laboratoire de Géologie, Parc de Grandmont, 37200 Tours, France

* Corresponding author. E mail address: Jean-Robert.Disnar@univ-orleans.fr

\begin{abstract}
The Sarliève marsh in the Limagne plain, in the heart of the French Massif Central, functioned as an endorheic lake during the Late Glacial and the Early and Middle Holocene. During the Late Boreal and the Atlantic it experienced drastic lowering of the water level as a result of dry and warm climatic episodes. Then, pre-evaporitic conditions triggered the deposition of sediment rich in organic matter $(\mathrm{OM})$ and in carbonates including dolomite. Fifty one samples from a ca. $1.8 \mathrm{~m}$ sediment core section covering the period were analysed using Rock-Eval pyrolysis and gas chromatography-mass spectrometry (GC-MS). Throughout the interval, the organic matter content remained notable to high [up to $13.35 \%$ total organic carbon (TOC)] and of good quality as indicated by low Oxygen Index (OI) values ( $\left.<200 \mathrm{mg} . \mathrm{CO}_{2} \mathrm{~g}^{-1} \mathrm{TOC}\right)$ and high Hydrogen Index (HI) values (160-660 $\mathrm{mg} \mathrm{HC} \mathrm{g}^{-1}$ ) which, as a rule, increased with increasing TOC content.
\end{abstract}

In contrast to the acid fractions, which sometimes contained notable proportions of $n-\mathrm{C}_{16}$ or $n-\mathrm{C}_{18}$ fatty acids (FAs; analysed as the methyl esters, FAMEs), the neutral fractions were almost devoid of low molecular weight compounds. The latter were probably biodegraded during early diagenesis. Conversely, high molecular weight compounds were abundant in both fractions and were dominated by $n$-alkanols, $n$-alkanes, steroids and hopanoids in the neutrals and evennumbered FAs and hopanoids in the acid fractions. The hopanoids were dominated by regular 
bishomohopanoids, accompanied by 2-methylated bishomohopanoids, as well as by unidentified bishomohopanoids with methylation in either the D or E ring. These distributions, typical for bacteria, provide support for previous hypotheses on the contribution of microorganisms to the studied record and for providing conditions for the precipitation and growth of dolomite and other pristine carbonate minerals [Bréheret, J.G., Fourmont, A., Macaire, J.J., Négrel, Ph., 2008. Microbially mediated carbonates in the Holocene lacustrine deposits of the Marais de Sarliève (French Massif Central) testify to the evolution of a restricted environment. Sedimentology 55, 557-578]. The preservation of the compounds was probably ensured by persistent reducing conditions during diagenesis, despite variable climatic conditions and related changes in lake level and sedimentation rate. Comparable distributions of hopanoic acids and hopanols, as well as roughly parallel variation with depth in the corresponding components in both fractions, strongly suggest that all the hopanoids derive from the same microbial precursors, slight shifts in the acid/alcohol ratio being governed by limited changes in redox conditions during early diagenesis.

\section{Introduction}

Microbial mats are considered as the most ancient ecosystems on Earth existing for over 3 billion years (Hofmann et al., 1999; Schopf, 2006; Dupraz et al., 2009). They have played a crucial role in the evolution of the terrestrial environment through the realisation of highly specialized metabolic reactions, such as photosynthesis, responsible for the oxygenation of the atmosphere (e.g. Westall, 2005; Tomitani et al., 2006; Buick, 2008), as well as $\mathrm{N}_{2}$ fixation and even $\mathrm{H}_{2}$ production (Hoeler et al., 2001). As exemplified by the well-known Precambrian stromatolites (Lepot et al, 2008), microbial sediments are sometimes also a site for carbonate formation, including dolomite (Dupraz et al., 2004, 2009 and refs. therein). Dolomite remains a mysterious mineral. The various unknowns and controversies about its formation have been collectively titled "the dolomite problem" (Zenger et al., 1980; Vasconcelos and McKenzie 1997; Warren, 2000). Despite thermodynamically favourable conditions (oversaturation of its components), it does not precipitate in seawater or hypersaline lakes (Arvidson and Mackenzie, 1999; Warren, 2000). In addition, attemps to precipitate it under abiotic conditions in the laboratory were unsuccessful (e.g., Land, 1998). Altough it is common in the geological record, it is presently only formed - via still obscure mechanisms - in a limited number of marine settings or saline 
lakes (van Lith et al., 2003; Vasconcelos and McKenzie, 1997; Wright, 1999; Sadooni et al. 2010). A number of such lakes occur in America and Australia (Last, 1990) but few in Europe, and none in France. Recent work on the Holocene record of the Sarlieve palaeolake, in the heart of the French Massif-Central, revealed the unexpected presence of sections rich in organic matter (OM) and pristine magnesian carbonates, especially dolomite (Bréheret et al., 2003; Fourmont, 2005; Fourmont et al., 2009). Their precipitation is supposed to have been mediated by microorganisms, under particularly dry climatic conditions (Bréheret et al., 2008). Accordingly, the first aim of the present work was to better characterize the OM of the section to obtain information on the source organisms and the conditions of deposition and diagenesis, a subordinate question being whether it might have contributed to dolomite formation. A second question was whether the organisms that contributed to the particular levels were limited to very specific (pre-evaporitic) conditions and thus to a short timespan, or whether they could have survived much longer, especially during the following rise in the lake water table level. Finally, the mid-Holocene (Late Boreal-Atlantic) age of the deposit also offered the opportunity to establish a link between ancient and recent sediments and thus to determine which biological markers survived early diagenesis and were therefore candidates for further fossilisation.

\section{Geological setting}

The Sarliève palaeolake $\left(4.5 \mathrm{~km}^{2}\right)$, drained since the 17 th Century, is in the Oligocene Limagne rift, which divides the northern part of the French Massif Central in a north-south direction. It is ca. $5 \mathrm{~km}$ south of Clermont-Ferrand, at an altitude of ca. $345 \mathrm{~m}$. The catchment area of the palaeolake covers $29 \mathrm{~km}^{2}$ (Fig. 1). It is composed of Upper Oligocene marls and limestones, partially dolomitic, and is locally rich in gypsum (with several interbedded basaltic tuffs), and of a small Miocene analcime-rich basanite plateau. These rocks are strongly weathered and reworked in superficial formations (Jeambrun et al., 1973). River deposits occur as a terrace inherited from the Allier River (Lenselink et al., 1990).

The now totally dry "Sarliève marsh" was a lake during the Late-Glacial-Holocene (Bréheret et al., 2003; Fourmont, 2005; Fourmont et al., 2009). The sediment fill, 6m thick at its maximum, comprises Late Glacial-Holocene silty marls. This study was originally undertaken to reconstruct the local hydrological evolution and the climate vs. human impact on sediment yield from 
sediment stores since the Late Glacial (Fourmont, 2005; Fourmont et al., 2009; Macaire et al., 2010). In addition to detailed mineralogical investigations, the OM composition was characterized by Rock-Eval pyrolysis and palynofacies were examined (Fourmont, 2005). Special attention was paid to the pristine carbonates, dolomite and aragonite, that are particularly abundant in the middle part of the record (Boreal and Atlantic), where they often built up variably thick stacks of OM-rich laminae (Bréheret et al., 2008). At the scale of scanning electron microscopy (SEM) the dolomite-rich levels revealed an abundance of tiny crystals (tens to hundreds of $\mathrm{nm}$ ) mainly organized as microspheres resembling cocci or bacilli. Such a facies is commonly interpreted as resulting from the fossilization of benthic microbial communities by dolomite. This kind of dolomite, rather unusual in western Europe, was precipitated in a saline environment as a consequence of excess evaporation from the system (Bréheret et al., 2008). This study deals with a ca. 1.8m section (between 2.02 and $3.80 \mathrm{~m}$ depth in core Sarl 17b) deposited during the Late Boreal and the Atlantic [the age assignments are based on palynological studies (Argant and Lopez-Saez, 2004) and a few unpublished radiocarbon dates]. This interval covers a transition between an endorheic stage and an open lake stage.

\section{Material and methods}

Core SARL 17b was drilled using a percussion corer (Eijelkamp FB 60; Atlas Copco Berema $\mathrm{AB}$, Stockholm, Sweden) and 51 non adjacent samples were taken according to the different facies recognized. Two intervals $(2.30-2.38 \mathrm{~m}$ and $2.56-2.74 \mathrm{~m})$ were not suitable for analysis because of drilling disturbance.

Rock-Eval pyrolysis was carried out on $100 \mathrm{mg}$ of powdered dry sediment with a "Turbo" Rock-Eval 6 pyrolyser (Vinci Technologies). The full description of the method and the resulting parameters is given by Espitalié et al. (1985) and Lafargue et al. (1998). Total S content was determined after combustion with a Leco CNS analyzer. Carbonate content was determined with a Bernard calcimeter (Jeulin, Evreux, France). Powder X-ray diffraction (XRD) with a Rigaku diffractometer (Rigaku Corporation, Tokyo, Japan; Elexience, Verriere-le-Buisson, France) was used for bulk mineral identification.

\subsection{Lipid extraction and fractionation}


Aliquots $(2 \mathrm{~g})$ of dried samples were soaked overnight in acetone-pentane (1:1), with a 1:10 w/v sample:solvent ratio. The mixture was sonicated $(2 \times 5 \mathrm{~min})$ at ambient temperature and centrifuged. The surpernatant was collected and the sediment rinsed with fresh solvent. The latter operation was repeated, and the extract and washes combined and the solvent removed under vacuum. Heptylbenzoic acid and dodecylbenzene were used as internal standards (for the acids and neutrals, respectively).

The extracts were separated into neutrals and acids using column chromatography on $\mathrm{KOH}$ impregnated silica gel columns (McCarthy and Duthie, 1962). The acids, eluted with diethyl ether/HCOOH (9:1, v/v), were concentrated and esterified with $\mathrm{CH}_{2} \mathrm{~N}_{2}$ (Lombardi, 1990); the neutrals, eluted with diethyl ether, were converted to trimethylsilylethers (TMSE) using N,Obis(triméthylsilyl)trifluoroacetamide (with 1\% trimethylchlorosilane; BSTFA/TMCS, SigmaAlldrich).

After derivatization, both neutral and acidic fractions were diluted with 50 or $100 \mu \mathrm{CH}_{2} \mathrm{Cl}_{2}$ and analysed using gas chromatography-mass spectrometry (GC-MS) with a TRACE-PolarisGCQ instrument. The gas chromatograph was fitted with a Rtx-5MS column (30 m, $0.25 \mathrm{~mm}$ i.d., 0.25 $\mu \mathrm{m}$ film thickness) with a $5 \mathrm{~m}$ guard column. The $\mathrm{GC}$ operating conditions were: $40{ }^{\circ} \mathrm{C}(1 \mathrm{~min})$ to $120{ }^{\circ} \mathrm{C}$ at $30{ }^{\circ} \mathrm{C} \mathrm{min}-1$, then to $300{ }^{\circ} \mathrm{C}$ (held $30 \mathrm{~min}$ ) at $3{ }^{\circ} \mathrm{C} \mathrm{min}^{-1}$. The sample was injected splitless, with the injector temperature set at $280{ }^{\circ} \mathrm{C}$. The carrier gas was He. The mass spectrometer was operated in the electron ionisation (EI) mode at $70 \mathrm{eV}$ and scanned from $\mathrm{m} / \mathrm{z} 50$ to 600 .

\section{Results}

The core (Fig. 2) displays variably distributed homogeneous sections separated by others which show various sedimentological features such as lamination or bioturbation mark. The 51 samples, taken to represent the different facies, generally consist of non-adjacent sections of variable thickness that are sedimentologically as homogeneous as possible. The sedimentological features, especially the lamina bundles, are more abundant in the lower part of the core that also is richer in dolomite and TOC (max. $13.35 \mathrm{wt} \%$ at $3.48 \mathrm{~m}$ depth; Fig. 2). In the dolomite-poor upper part of the core, a relatively high TOC value of $5.20 \%$ at $2.52 \mathrm{~m}$ also coincides with a high content of this mineral. HI values are generally rather high (between 160 and $660 \mathrm{mg} \mathrm{HC} \mathrm{g}^{-1}$ ), the highest 
values being in OM-rich levels. OI values are rather low ( $<200 \mathrm{mg} \mathrm{CO}_{2} \mathrm{~g}^{-1}$ TOC) and nearly constant throughout the section. S content is globally very low; the highest values hardly reaching $0.2 \%$ near the base of the section. In contrast to aragonite, present in low proportions in a few more or less scattered levels, the dolomite content varies irregularly but also follows a general decreasing upward trend. The dolomite content also shows an obvious correlation with TOC (Fig. 2).

The fatty acids (as methyl esters FAMEs; e.g. Fig. 3) show the classical predominance of even numbered components at $\mathrm{C}_{16}$ and $\mathrm{C}_{18}$ among the $<\mathrm{C}_{20}$ components, and at $\mathrm{C}_{24}-\mathrm{C}_{30}$ in the high molecular weight (HMW) range. Nevertheless, these compounds are outweighed by the $\beta \beta$ bishomohopanoic acid (Ha3), accompanied by notable amounts of a 2-methylbishomohopanoic acid (Ha2) and another unidentified hopanoic acid (Ha1; Section 5.4). As shown in Fig. 4, the neutral lipid distributions analogously show high proportions of $\beta \beta$-bishomohopanol $\left(\mathrm{H}_{\mathrm{OH}} 3\right.$; as TMSE) accompanied by notable proportions of methylated bishomohopanols $\mathrm{H}_{\mathrm{OH}} 1$ and $\mathrm{H}_{\mathrm{OH}} 2 \mathrm{a}$. These hopanols are accompanied by lower, but non-negligible, proportions of more common hopanoids, namely 30-norhop-22(29)-ene, hop-22(29)-ene (diploptene) and hop-21-ene. Despite the abundance of the hopanoids, the neutral fractions are classically dominated by even $n$ alkanols dominated by $\mathrm{C}_{26}-\mathrm{C}_{30}$ components. $n$-Alkanes and sterols and stanols also are abundant. The $n$-alkanes display the classical predominance of odd HMW homologues with a mode at $n$ - $\mathrm{C}_{27}$ or $n-\mathrm{C}_{29}$ (low MW range not shown in Fig. 4). Sterol and stanol distributions comprise the common $\mathrm{C}_{27}, \mathrm{C}_{28}$ and $\mathrm{C}_{29}$ components (Fig. 4 caption), with the latter, 24-ethylcholest-5-en-3 $\beta$-ol and 24-ethylcholestan-3 $\beta$-ol, always predominant over the lower homologues. The variation in abundance of various individual compounds throughout the section is compared with TOC in Fig. 5. The componentss selected are (i) most of the hopanoids in the neutral and the acid fraction (these play an important part in the following discussion) and (ii) a few components typical of major biological sources, with the aim of appreciating the major contributions to the TOC. In this regard, the $n-\mathrm{C}_{26: 0}$ FAME and $n-\mathrm{C}_{26}$ alkanol were chosen as representative of the dominant compounds in the acid and neutral fractions, respectively. Within the LMW FAMEs, $n-\mathrm{C}_{16}$ and $n$ $\mathrm{C}_{18}$ do not show any correlation and are only present in a few levels in the lower part of the core. In contrast, the $n-\mathrm{C}_{26: 0} \mathrm{FAME}$ is present at notable levels and constitutes a more or less regular background along the section, virtually without any correlation with TOC. The $n-\mathrm{C}_{26}$ alkanol also is present all along the series, but displays a more or less regular variation of much larger 
amplitude and period (decimetric or even greater) than the $n-\mathrm{C}_{26: 0}$ FAME. Even if it is difficult to suggest a correlation between both parameters, there is some correspondence between the variation in the amount of $n$-docosanol and TOC. There are obvious correlations between the hopanoids in the acid and neutral fractions, respectively, and, to a lesser degree, between all components in these fractions. These compounds are also more abundant near the base of the section and show a variable but obvious correlation with TOC.

The mass spectra of a stanol tentatively assign as epi-campestanol (see below) is displayed in Fig. 6 , together with the mass spectra of an unknown hopanol and the corresponding hopanoic acid.

\section{Discussion}

When the variations in the dolomite content and OM, as well as the vertical distributions of various molecular markers (Fig 5) are examined, more or less progressive changes appear roughly around the middle of the record. However, because of the absence of a clear-cut boundary between these changes, in the following discussion the upper and lower parts of the core are designated as such, without further specification.

\subsection{Biomarker source and diagenesis}

\subsubsection{Non-hopanoids}

The $n-\mathrm{C}_{16: 0}$ and the $n-\mathrm{C}_{18: 0}$ FAs are essential components of the cell membrane of most living organisms (excluding Archaea, whose membrane lipids are mainly composed of isoprenoid ethers). However, in contrast to the LMW FAMEs of terrestrial plants, which are easily destroyed in the upper layers of soil (Marseille et al., 1999), those of aquatic organisms can escape degradation under anoxic conditions (Stefanova and Disnar, 2000 and refs. therein). In the core, $n-\mathrm{C}_{16: 0}$ or $n-\mathrm{C}_{18: 0}$ (or one of their monounsaturated counterparts; data not shown), which are presumably of autochthonous origin, are present in only a few bottom layers (Fig. 5) suggesting that they were degraded elsewhere during early diagenesis (Lehtonen and Ketola, 1993; Ficken et al., 1998). This contrasts with the HMW FAMEs usually derived from higher plants (see below) that are present in all the samples. For example, $n-\mathrm{C}_{26: 0}$ (Fig. 5) occurs at a concentration that fluctuates around a mean background value of ca 3-4 $\mu \mathrm{g} \mathrm{g}^{-1}$, indicating a rather constant input of well-preserved higher plant remains. Like the HMW FAMEs, but not the acid and neutral 
bishomohopanoids, most of the compounds of relatively high MW: $n$-alkanes, $n$-alcohols and $\mathrm{C}_{29}$ sterols and their stanol counterparts (Figs 3 and 4) are classically assigned to higher plants or, more specifically, to their leaf cuticular waxes. In the present case two different major sources can be suspected: (i) higher plants from the watershed (i.e. trees, bushes or even grasses) and (ii) emerged macrophytes such as reeds and rushes. While grasses can be excluded since they contain heavier components than those here [e.g. $\mathrm{C}_{31} / \mathrm{C}_{33} n$-alkanes predominant (Rommerskirchen et al., 2006)], helophytes provide the same type of long chain compounds as trees (Barnes and Barnes, 1978; Cranwell, 1984).

The low water level at the time of deposition (Bréheret et al., 2008) was likely favourable for the existence of a large border of helophytes and/or an extensive hydrophyte meadow (Ruppia sp.), directly providing OM to the sediment (and probably also acting as a barrier for particulate terrestrial input). This possibility is supported by the frequent co-occurrence of rather high concentrations of higher plant-derived $n-\mathrm{C}_{26}$ alkanol and high TOC values (Fig. 5), strengthening the idea that OM-richness in this case is not strictly governed by greater OM production by a few specific organisms, but also by a simple lowering of inorganic input, thereby entailing the simultaneous accumulation of organic components from all sources. A predominant higher plant origin - i.e. macrophytic for the above reasons- can also be proposed for the dominating $\mathrm{C}_{29}$ sterols and stanols (Figs 3 and 4); however, algae and/or microbiota also could have contributed (Volkman, 1986; Pearson et al. 2007). While it is generally considered that diatoms are the most likely contributors to the $\mathrm{C}_{28}$ steroids (see below), most of the $\mathrm{C}_{27}$ components, especially cholesterol, are of ubiquitous origin.

The excellent preservation of $n$-alkanols as indicated by their predominance over $n$-alkanes, is compatible with a rather short residence time in soils and a fast transport to the lake via runoff (some aerial transport also being possible: Simoneit, 1997; Lopez-Martinez et al., 2006). The striking difference in the variation with depth of the $n-\mathrm{C}_{26: 0}$ FAME and the $n-\mathrm{C}_{26}$ alkanol concentration profiles most probably reflect differences in the mode of transport of both these terrestrial plant derived components to the lake.

\subsection{Hopanoids (and accompanying compounds)}

A salient point of the study is the abundance of hopanoids in most, or even all, samples, $\mathrm{C}_{32}$ components being predominant over all the other components in the acid and neutral lipid 
fractions (Figs. 3 and 4). The hopanoids occur mainly as acids and alcohols, apart from subordinate amounts of common alkenes with fewer carbons, 30-norhop-22(29)-ene, hop-22(29)ene (diploptene) and hop-21-ene. Hopanoids mainly play the role of sterol surrogates as components of the cell membrane almost exclusively in bacteria. A wide variety exists with most of the differences occurring in the length of the lateral chain and the number of the $\mathrm{N}$ or $\mathrm{O}$ containing functional groups it bears (Rohmer et al., 1984; Bisseret et al., 1985; Talbot et al., 2008 and refs. therein). However, some compounds differ from regular hopanes via some more or less subtle changes in the polycyclic backbone. Among these, one of the most interesting from a taxonomic point of view is the presence of an extra methyl on ring $\mathrm{A}$, either at $\mathrm{C}-2$ or $\mathrm{C}-3$. The $\beta$ orientation of this extra Me has been demonstrated for the 2- and 3-methylhopanes (Summons and Jahnke, 1992). Because of the earlier discovery of 3-methylhopanoid precursors in the biological realm (Rohmer and Ourisson, 1976), all sedimentary methylhopanes were thought to have this structure before the 2-methyl isomers were identified.

Prior to 2000, it was commonly accepted that 2-methylhopanes were typical markers of cyanobacteria (Summons et al., 1999; Farrimond et al., 2004). However, it has been recently evidenced that not all cyanobacteria produce such compounds (namely 21 out of the 58 species tested by Talbot et al., 2008). In addition, a few other bacteria have been shown to produce them (Zundel and Rohmer, 1985; Rashby et al., 2007 and Welander et al. 2010 for bacteriohopanepolyols and Vilchèze et al., 1994 for a methyldiplopterol). Thus, if the contribution of cyanobacteria cannot be assessed from the abundance of methylhopanoids, supporting evidence for the formation of a microbial mat (with a possible participation of these organisms) is provided by the co-occurrence of high proportions of regular bishomohopanoic acid and alcohol in the acid and neutral fractions as well as by more general criteria such as the occurrence of high levels of these biomarkers in TOC-rich laminae (together with other geochemical and sedimentological features; Bréheret et al., 2008). Photosynthetic (cyano)bacteria are generally thought as pioneers in the building of mats and continue to grow at the surface during mat development. However, those that develop first are rapidly overgrown by new populations and die, the remains of the dead organisms being then used by non-photosynthetic heterotrophs. These succeed each other, depending mostly on the availability of oxidants, i.e. aerobic heterotrophic bacteria, sulfur-oxidising chemolithotrophs, anoxygenic phototrophic bacteria and sulfate reducers. Various fermentative microorganisms (e.g., methanogens, nitrifying 
or denitrifying bacteria) also are present in the mats but in lower numbers (van Gemerden, 1993; Fourçans, 2004; Fourçans et al., 2004). The growth and metabolic activity of these organisms result in vertical physicochemical gradients of oxygen, sulfide and light (Jørgensen et al., 1983; Revsbech et al., 1983). Another important consequence of this succession of organisms is that the latest ones thrive on the remains of the previous ones and thus generally destroy molecular indicators of their past presence and activity, thereby leaving little evidence of the primary ones.

Supporting evidence for a contribution of cyanobacteria could have been given by $\mathrm{C}_{17}-\mathrm{C}_{19}$ methylalkanes (or methylalkenes), which are the most frequently mentioned biomarkers of these organisms (Boudou et al., 1986; Shiea et al., 1990; Hefter et al., 1993; Kenig et al., 1995; Köster et al., 1999 in Jungblut et al., 2009; Scherf and Rullkötter, 2009; Maliński et al., 2009). At Sarliève these compounds are only present at low levels or are even missing. Consistent with various reports of their rather rapid disappearance in microbial sediments (Boon et al., 1983; Grimalt et al., 1992; Rontani and Volkman, 2005) they were probably detroyed during early diagenesis, like the LMW FAs (Section 5.1.1).

Despite the large variation in component concentration between the lower and the upper parts of the core, the roughly parallel variation with depth in the hopanoids points to the same microbial community thriving in the lake during the timespan covered by the section. It can therefore be assumed that most or even all the hopanoids derive from the same precursor compound(s), and that the acid/alcohol ratio (Fig. 5) varied, depending on redox medium conditions. Higher hopanoid acid/alcohol ratio values at the base might be taken as an indication of slightly less reducing conditions, whereas lower values in the upper levels are consistent with even lower oxygenation. This is a consequence of the rise in water level suggested by various observations (Fourmont et al., 2009), including a decrease in microbial production revealed by the following: lower TOC values (Fig. 2), lower amounts of pristine carbonates (dolomite and aragonite; Fig. 2), fewer laminae, etc. This point is further discussed in the next section.

\subsection{Environmental conditions during deposition}

The Sarlieve paleolake is located in an area of somewhat flat topography in the southern part of the intramontanous Limagne plain. Presently, the area is rather dry, with a mean annual precipitation $<600 \mathrm{~mm}$. The aridity might have been even more pronounced in earlier times, 
especially when the sediments were deposited, i.e. during the Late Boreal and the Atlantic. At that time, during which the Earth underwent global warming, the lake was endorheic. Then, the low water level favoured the concentration of salts released from the weathered Oligocene substratum formations. These conditions were well established via the presence of remains of adapted biological species (especially Campylodiscus clypeus Ehrenberg, a mesohalobe diatom, Charophyte Chara cf. canescens Loiseleur and the hydrophyte Ruppia sp.; Bréheret et al., 2003). These characteristics were probably typically those when the lower third of the core was deposited being richer in autochthonous carbonate minerals and in regular and 2-methyl bishomohopanols and bishomohopanoic acids. In addition to dolomite precipitation (known to be effective under anoxic conditions; see next section), other clues indicate that diagenesis of the corresponding sediment section occurred in overall anoxic conditions. Organic geochemical evidence for this interpretation is provided by the following observations (Figs. 2 and 5): high TOC content and excellent preservation of the OM as depicted by high and low HI and OI values, respectively, as well as by the richness in biomarkers, especially the labile ones (e.g., $n$-alkanols; see below), high abundance of reduced forms of some biomarkers relative to their oxidised counterparts (e.g., hopanols vs. hopanoic acids) and abundance of reduced derivatives of some biological components such as stanols, which dominate their sterol counterparts throughout the section. These features are not limited to the lower part of the core, where dolomite is abundant, but also occur in the upper part, despite different depositional conditions.

The age of the sediments between 3.68 and $3.28 \mathrm{~cm}$ (8200 to $7200 \mathrm{BP})$ is constrained by several radiocarbon dates that allowed us to estimate a mean sedimentation rate at ca. $0.4 \mathrm{~mm} \mathrm{y}^{-1}$. Such a low rate is consistent with a predominantly chemical (carbonates) and biochemical [e.g., diatoms and (cyano)bacteria] sedimentation. A few radiocarbon dates from the top of the main episode of lamination (L4) at about $3.451 \mathrm{~m}$, up to $2.93 \mathrm{~cm}$ suggest that the sedimentation rate increased significantly during deposition of the corresponding sediment section, probably up to more than $1.5 \mathrm{mmy}^{-1}$ (unpublished results). This change in sedimentation rate is substantiated by a net sedimentological and lithological change, with the almost total disappearance of laminae and the deposition of rather large sections of homogenous marls (Fig. 2). Basically, this change - also substantiated by a notable input of clay minerals - is probably related to an increase in precipitation that entailed greater weathering and detrital input to the lake, inducing a rise in its level. In the lower part of the core, OM preservation was probably controlled by high biological 
productivity and rapid development of anoxic conditions (see above) thanks to very active microbacterial growth and diagenesis. In contrast, in the upper part of the core, much lower TOC values denote lower OM production and additionally much greater dilution by the mineral input (Fig. 5). These different sedimentation conditions nevertheless apparently ensured as efficient OM preservation as in the lower part. This is particularly underlined by hopanol/hopanoic acid values that, on average, are only slightly lower in the upper part of the core despite much lower component concentrations (Fig. 5).

\subsection{The dolomite problem}

The microbial mat that probably gave rise to the laminae that are common in the bottom part of the sequence (Breheret et al., 2008) also provided the grounds for the formation of dolomite and other carbonates (Fig. 2). The effective role(s) the microbiota plays in the precipitation of carbonates is still a matter of debate (Dupraz et al., 2009 and refs. therein). The direct participation of the microbial organic matrix as a template for mineral formation has long been assumed for calcite or aragonite (e.g. Trichet and Defarge, 1995). In contrast, until recently, only an indirect contribution from microorganisms was assumed for dolomite formation. In their pioneering work on the lagoon of Vermelha sediments (Brazil), Vasconcelos and McKenzie (1997) assumed that dolomite formation was mediated by sulfate-reducing bacteria (SRB). In fact, the role attributed to these organisms was first the removal of sulfate, assumed to be an inhibitor to dolomite formation, and second to help overcome the kinetic energy barrier of the precipitation process by increasing $\mathrm{pH}$ and carbonate alkalinity. This SRB concept was effectively supported by laboratory work with Desulfovibrio (Warthmann et al., 2005), but some time later methanogens also were shown to be capable of promoting dolomite formation (Kenward et al. 2009). However, field and laboratory evidence supporting this microbially mediated dolomitisation process remains scarce and implies specific medium conditions that may not hold for the genesis of all dolomite occurrences. Recent work on ancient and recent formations of the Abu Dhabi coastal sabkha (Bontognali et al., 2010) led the authors to admit that if the microbially mediated dolomite formation holds for the infratidal sediments, it could not be invoked for the supratidal sediments. In the latter case, the authors assumed that, in the absence of metabolizing microbes, dolomite formation was promoted thanks to the mineral-template properties of the organic matrix of the microbial mat. As a matter of fact, this latter one is able of 
preferentially binding $\mathrm{Mg}$ (and $\mathrm{Si}$ ) over $\mathrm{Ca}$ ions, supposed to have the crucial consequence of overcoming the kinetic barriers that normally prevent nucleation of dolomite at low temperature. A study of Miocene lacustrine stromatolites also led Sanz-Montero et al. (2008) to emphasize the template role that the microbial organic matrix is capable of playing in dolomite (and silica) crystal formation and growth. In addition, culture experiments with halophilic aerobic bacteria demonstrated that, in contrast to what was commonly reported for years, dolomite precipitation is not inhibited in the presence of sulfate (Sánchez-Román et al., 2009), reducing the part possibly played by SRB in this process.

In this context of rapidly changing ideas on dolomite formation the main observations for the Sarliève sediments are that dolomite and other autochthonous carbonates accumulated in sediments rich in TOC and in methyl and regular hopanoids under (pre)evaporitic conditions. All these features are normally characteristic of, or even typical of, microbial mats. The exact role the microrganisms and/or their OM played in the precipitation of dolomite and other carbonates remains uncertain. Bréheret et al., 2008 suggested that SRB likely were responsible for dolomite precipitation at Sarliève, the hypothesis being sustained by the observation of a few sulfide minerals. If notable S levels of ca. $0.2 \%$ occur in a few levels (Fig. 2), the concentration is not high and $\mathrm{S}$ is present at much lower content elsewhere, even in the lower part of the core. In addition, there is no straightforward correlation between $\mathrm{S}$ and TOC and/or dolomite. Furthermore, $\mathrm{S}$ is not all in the form of sulfides, gypsum having also been observed frequently with SEM (Fourmont, 2005). Stable carbon isotope ratio values of the dolomites, ranging from -8 to $-4 \%$ (Bréheret et al., 2008), indicate a contribution from light carbon, probably released by heterotrophs that thrived at the expense of the microbial matrix, a contribution from SRB not being excluded, even if likely not exclusive. Nevertheless, the most probable role played by the microbial mat was to act as a template for mineral formation and growth.

\subsection{Unknown stanols and hopanoids}

Two $\mathrm{C}_{28}$ stanols were found in most samples. Campestanol (24-methyl-5 $\alpha$-cholestan-3 $\beta$-ol) was assigned from its mass spectrum and retention time (midway between cholestanol and stigmastanol). The second $\mathrm{C}_{28}$ stanol has the same mass fragmentation as campestanol (Fig. 6) but elutes earlier, in fact rather close to cholestanol. Since methylcoprostanol (5 $\beta$-24methylcholestan-3 $\beta$-ol) would be expected to coelute with cholestanol, an epi-campestanol $(5 \alpha-$ 
24-methylcholestan-3 $\alpha$-ol) can be suspected. The epi configuration is unusual among biological steroids, but nevertheless high levels of epi-brassicasterol (24-methylcholesta-5,22E-dien-3 $\beta$-ol) have been found recently in diatom-rich marine sediments (Mouradian et al., 2007). Reduction of this compound during early diagenesis would produce the assumed compound at the same time as cholesterol and its $\mathrm{C}_{28}$ and $\mathrm{C}_{29}$ homologues (the dominant steroids) produce the corresponding stanols (Fig. 4). This explanation does not exclude other possibilities, especially methylation of the cholestanol skeleton at an unusual position. As a matter of fact, both steroids and hopanoids originate from the cyclisation of squalene followed by the elimination of at least one methyl group, the number rising to three for regular steranes: two methyls at C-4 and one at C-14. It is therefore quite straightforward to hypothesize that the extra methyl in the unidentified $\mathrm{C}_{28}$ component could be the one linked to $\mathrm{C}-14$ and that was not eliminated in the course of biosynthesis. A similar hypothesis has been formulated by Boon et al. (1983) for an unusual $\mathrm{C}_{28}$ sterene in the Solar lake cyanobacterial mat. Although possible or even probable, the relationship between the latter compound and the Sarlieve unknown $\mathrm{C}_{28}$ stanol (Fig. 6) remains to be established, but strengthens the probability of a common stenol precursor from which both compounds originated, either by elimination of the hydroxyl at C-3 or by double bond reduction.

The presence of ions at $m / z 191$ and 383 in the spectra of the unidentified hopanoids reveals that these compounds bear an extra methyl on ring D or E. The origin of an additional methyl on the regular hopane skeleton raises a different question from that of the steroids, since regular hopanes originate from squalene cyclisation but without the loss or gain of a methyl. Nevertheless, the existence of methylated hopanes provides evidence that their producers are perfectly able of performing such a reaction that has effectively recently been supported by the discovery of a specialized methylase in various methylhopanoid producing microorganisms (Welander et al., 2010). The possible location of the extra methyl at C-21, at the junction of cycle D and of pentacyclic ring $\mathrm{E}$, would have the advantage of raising structural analogies with the unknown $\mathrm{C}_{28}$ stanol and may be indicative of a common biochemical (metabolic pathway) and/or even biological (source species) precursor for these two kinds of compounds.

\section{Conclusions}


Dry climatic conditions at the beginning of the Atlantic, favoured an abundant proliferation of microorganisms in the Sarliève paleolake in the French Massif Central. Especially during the deposition of the lower part of the record, intensive bacterial growth and activity is suggested by elevated concentrations of regular and 2-methyl hopanoid alcohols and acids, derived from higher MW precursors by way of partial breakdown of a polyfunctionalized lateral chain. An unknown hopanoid, likely bearing an additional methyl on ring D or E, would certainly be much more source specific than the 2-methylhopanoids. The growth of microorganisms triggered the deposition of carbonates - especially pristine dolomite - in or near OM rich levels (up to ca. 13\% TOC). Although mainly produced during a dry episode, under shallow water, the bacteria survived a rise in the water level, thereby still contributing episodically to the sediment OMrichness and dolomite formation. The relative proportions of related hopanoic acids and alcohols most probably varied with redox conditions during early diagenesis. However, these conditions certainly varied little during the deposition of the section, despite the notable rise in the lake water level and in detrital input, no doubt triggered by a wetter climate.

Few LMW biomarkers survived early diagenesis, attesting to the active reworking of these light compounds by the organisms that succeeded each other during sediment deposition and diagenesis. In contrast, the presence of HMW $n$-alkanols, $n$-alkanes and steroids in abundance and in relative proportions near those found in living plants is consistent with the good preservation of the bulk OM, as depicted by low and high OI and HI values, respectively. In contrast to the LMW compounds that suffered efficient bacterial reworking, the preservation of the HMW compounds and of high OM amounts was favoured by anoxic conditions. Probably as a result of the high microbial activity the conditions remained anoxic during the deposition of the whole section, despite notable changes in the climate, lake vegetation and sedimentation regime.

\section{Acknowledgements}

The work was supported by the CNRS-INSU ECLIPSE program "Anthropogenic impact upon soil erosion and sediment deposition in associated wetland areas during the Holocene period". The authors express their sincere thanks to the anonymous referees who reviewed the paper, for thoughtful comments that greatly helped improve the manuscript. A. Durand is also thanked for GC-MS and E. Rowley-Jolivet for corrections to the English. 


\section{Captions of figures}

Fig. 1. Location of Sarliève paleolake in its catchment area (Limagne rift, French Massif Central), after Brehéret et al. (2008).

Fig. 2. Lithology of core, with indication of carbonate content as well as OM abundance and quality, expressed as TOC content (\%) and values of the hydrogen index (HI, mg hydrocarbon $\mathrm{g}^{-1}$ TOC) oxygen Index (OI, mg CO $2 \mathrm{~g}^{-1} \mathrm{TOC}$ ), all determined using Rock-Eval pyrolysis, plus total $\mathrm{S}$ content (wt \%).

Fig. 3. Example of FA (as Me esters) distribution (sample 12, $3.48 \mathrm{~m}$ ). Assignments: FAs (labelled with a star), IS ( $n$-heptylbenzoic acid), hopanic acids Ha1 to Ha3: unknown bishomo methylhopanoic acid, $\beta, \beta$-methyl-2-bishomo-hopanoic acid, $\beta, \beta$-bishomohopanoic acid, respectively).

Fig. 4. Partial reconstructed total ion chromatogram (TIC) with single ion selective detection of major families of compounds in the neutral lipid fraction of samples 12 and 41 (3.48 and 2.52m, respectively): sterols $(\mathrm{m} / \mathrm{z}, 255)$, stanols $(\mathrm{m} / \mathrm{z}, 215)$ and hopanoids $(\mathrm{m} / \mathrm{z}, 191+205)$.

Compound assignment: $n$-alkanols and $n$-alkanes, labelled on the TIC with a circle and a star,

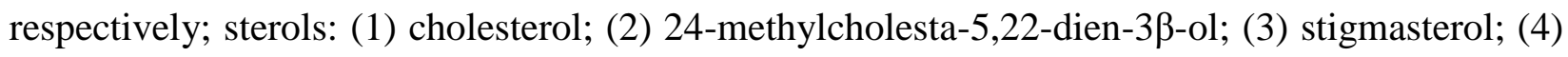

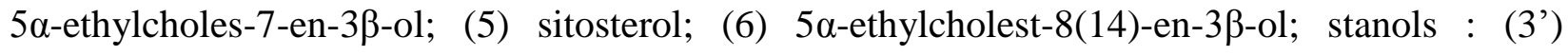
cholestanol (4') epicampestanol (see discussion); (5') ethylcoprostanol; (6') campestanol; (7') stigmastanol; hopanols (as TMS ethers) and other hopanoids: (a) 30-norhop-22(29)-ene; (b) hop22(29)-ene; $\quad$ (c) hop-21-ene; $\quad\left(\mathrm{H}_{\mathrm{OH}} 1\right) \quad \beta, \alpha$-bishomo-methyl-?-hopanol; $\quad\left(\mathrm{H}_{\mathrm{OH}} 2\right) \quad \beta, \beta$-2methylbishomo-hopanol; $\left(\mathrm{H}_{\mathrm{OH}} 3\right) \beta, \beta$-bishomohopanol.

Fig. 5. Variation with depth in concentration of selected compounds from the acid and neutral fractions. TOC variation is presented for comparison. See Fig. 3 caption for the identity of Ha1Ha3. 
Fig. 6. Mass spectra of unidentified compounds: (a) a stanol tentatively assigned as epicampestanol and (b and c) a methylated bishomohopanol (as trimethylsilyl ether) and the corresponding acid (as methyl ester), respectively.

\section{References}

Argant, J., Lopez-Saez, J.-A., 2004. L'occupation humaine du bassin de Sarliève depuis le Néolithique d'après la palynologie et l'étude des microfossiles non polliniques. 5e Rencontres méridionales de Préhistoire récente. Auvergne et Midi, actes de la cinquième session. ClermontFerrand, novembre 2002, Préhistoire du Sud-ouest suppl. 9, 25-34.

Arvidson, R.S., Mackenzie, F.T., 1999. The dolomite problem: control of precipitation kinetics by temperature and saturation state. American Journal of Science 299, 257-288.

Barnes, M.A., Barnes, W.C., 1978. Chapter 5: Organic compounds in lake sediments. In: Lerman, A. (Ed.), Lakes: Chemistry, Geology, Physics. Springer-Verlag, New York, pp. 127152.

Bisseret, P., Zundel, M., Rohmer, M., 1985. Prokaryotic triterpenoids 2. 2 $\beta$-Methylhopanoids from Methylobacterium organophilum and Nostoc muscorum, a new series of prokaryotic triterpenoids. European Journal of Biochemistry 150, 29-34.

Bontognali, T.R.R., Vasconcelos, C., Warthmann, R.J., Bernasconi, C., Dupraz, S., McKenzie, J.A., 2010. Dolomite formation within microbial mats in the coastal sabkha of Abu Dhabi (United Arab Emirates). Sedimentology 57, 824-844.

Boon, J.J., Hines, H., Burlingame, A.L., Klok, J., Rijpstra, W.I.C., de Leeuw, J.W., Edmunds, K.E., Eglinton, G., 1983. Organic geochemical studies of Solar Lake laminated cyanobacterial mats. In: Bjorøy, M. et al. (Eds.), Advances in Organic Geochemistry 1981. John Wiley and Sons, Chichester, pp. 207-227. 
Boudou, J.P., Trichet, J., Robinson, N., Brassell, S.C., 1986. Profile of aliphatic hydrocarbons in a recent Polynesian microbial mat. International Journal of Environmental Analytical Chemistry 26, 137-155.

Bréheret, J.G., Macaire, J.J., Fleury, A., Fourmont, A., Soulié-Marsche, I., 2003. Indices de confinement dans les dépôts lacustres holocènes de Sarliève (Limagne, France). Comptes Rendus Géosciences (Paris) 335, 479-485.

Bréheret, J.G., Fourmont, A., Macaire, J.J., Négrel, Ph., 2008. Microbially mediated carbonates in the Holocene lacustrine deposits of the Marais de Sarliève (French Massif Central) testify to the evolution of a restricted environment. Sedimentology 55, 557-578.

Buick, R., 2008. When did oxygenic photosynthesis evolve? Philosophical Transactions of the Royal Society B: Biological Sciences 363, 2731-2743.

Cranwell, P., 1981. Diagenesis of free and bound lipids in terrestrial detritus deposited in a lacustrine sediment. Organic Geochemistry 3, 79-89.

Cranwell, P., 1984. Lipid geochemistry of sediments from Upton Broad, a small productive lake. Organic Geochemistry 7, 25-37.

Dupraz, C., Visscher, P.T., Baumgartner, L.K., Reid, R.P., 2004. Microbe-mineral interactions: early carbonate precipitation in a hypersaline lake (Eleuthera Island, Bahamas). Sedimentology $51,745-765$.

Dupraz, C., Pamela Reid R., Braissant, O., Decho, A., Norman, R., Visscher, P., 2009. Processes of carbonate precipitation in modern microbial mats. Earth-Science Reviews 96, 141-162.

Espitalié, J., Derro, G., Marquis, F., 1985. La pyrolyse Rock-Eval et ses applications. Revue de l’Institut français du Pétrole 40, 563-579. 
Farrimond, P., Talbot, H. M., Watson, D. F., Schulz, L. K., Willhelms A., 2004. Methylhopanoids: Molecular indicators of ancient bacteria and a petroleum correlation tool. Geochimica et Cosmochimica Acta 68, 3873-3882.

Ficken, K.J., Barber, K.E., Eglinton, G., 1998. Lipid biomarker, $\mathrm{d}^{13} \mathrm{C}$ and plant macrofossil stratigraphy of a Scottish montane peat bog over the last two millennia. Organic Geochemistry 28, 217-237.

Fourçans, A., 2004. Dynamique des communautés bactériennes de tapis microbiens soumis aux stress environnementaux. Thesis, University of Pau, 243p.

Fourçans A., García de Oteyza, T., Wieland, A., Solé, A., Diestra, E., van Bleijswijk, J., Grimalt, J. O., Kühl, M., Esteve, I., Muyzer, G., Caumette, P., Duran, R., 2004. Characterization of functional bacterial groups in a hypersaline microbial mat community (Salins-de-Giraud, Camargue, France). FEMS Microbiology Ecology 51, 55-70.

Fourmont, A., 2005.Quantification de l'érosion et de la sédimentation dans le bassin de Sarliève (Massif Central, France) au Tardiglaciaire et à l'Holocène. Impact des facteurs naturels et anthropiques. $\mathrm{PhD}$ thesis, University of Tours, $419 \mathrm{p}$.

Fourmont, A., Macaire, J.J., Bréheret, J.G., 2009. Contrasted Late Glacial and Holocene hydrology of Sarliève paleolake (France) from sediment geometry and detrital versus biochemical composition. Journal of Paleolimnology 41, 471-490.

van Germerden, H., 1993. Microbial mats, a joint venture. Marine Geology 113, 3-25.

Grimalt, J.O., de Wit, R., Teixidor, P., Albaiges, J., 1992. Lipid biogeochemistry of Phormidium and Microcoleus mats. Organic Geochemistry 19, 509-530. 
Hefter, J., Thiel, V., Jenisch, A., Galling, U., Kempe, S., Michaelis, W., 1993. Biomarker indications for microbial contribution to recent and late Jurassic carbonate deposits. Facies 29, 93-106.

Hoehler, T.M., Bebout, B.M., Des Marais, D.J., 2001. The role of microbial mats in the production of reduced gases on the early Earth. Nature 412, 324-327.

Hofmann, H.J., Grey, A.H., Hickman, A.H., Thorpe, R.I., 1999. Origin of 3.45 Ga coniform stromatolites in Warrawoona Group, Western Australia. Geological Society of America Bulletin $111,1256-1262$.

Jeambrun, M., Aubert, M., Bouiller, R., Camus, G., Cochet, A., d'Arcy, D., Giot, D., Baudry, D., Roche, A., Bonhommet, N. 1973.Carte géologique à 1/50000 de Clermont-Ferrand XXV-31 et notice, 64 pp. BRGM Editions, Orléans.

Jørgensen, B. B., Revsbech, N. P., Cohen, Y., 1983. Photosynthesis and structure of benthic microbial benthic microbial: microelectrode and SEM studies of four cyanobacterial communities. Limnology and Oceanography 28, 1075-1093.

Jungblut, A.D., Allen, M. A., Burns, B. P., Neilan, B.A., 2009. Lipid biomarker analysis of dominated microbial mats in meltwater ponds on the McMurdo Ice Shelf, Antarctica. Organic Geochemistry 40, 258-269.

Kenig, F., Sinninghe Damsté, J.S., Kock-van Dalen, A.C., Rijpstra, W.I.C., Huc, A.Y., de Leeuw, J.W., 1995. Occurrence and origin of mono-, di-, and trimethylalkanes in modern and Holocene cyanobacterial mats from Abu Dhabi, United Arab Emirates. Geochimica et Cosmochimica Acta 59, 2999-3015.

Kenward, P.A., Goldstein, R.H., Gonzalez, L.A., Roberts, J.A., 009. Precipitation of lowtemperature dolomite from an anaerobic microbial consortium: the role of methanogenic Archaea. Geobiology 7, 556-565. 
Köster, J., Volkman, J.K., Rullkötter, J., Scholz-Böttcher, B.M., Rethmeier, J., Fischer, U., 1999. Mono-, di- and trimethyl-branched alkanes in cultures of the filamentous cyanobacterium Calothrix scopulorum. Organic Geochemistry 30, 1367-1379.

Lafargue, E., Marquis, F., Pillot, D., 1998. Rock-Eval 6 applications in hydrocarbon exploration, production, and soil contamination studies. Revue de 1'Institut français du Pétrole 53, 421-437.

Land, L.S., 1998. Failure to precipitate dolomite at $25^{\circ} \mathrm{C}$ from dilute solution despite 1000 -fold oversaturation after 32 years. Aquatic Geochemistry 4, 361-368.

Last, W.M., 1990. Lacustrine dolomite - an overview of modern, Holocene, and Pleistocene occurrences. Earth Science Reviews 27, 221-263.

Lehtonen, K., Ketola, M., 1993. Solvent-extractable lipids of Sphagnum, Carex, Bryales, and Carex Bryales peats: content and compositional features vs. peat humification. Organic Geochemistry 15, 275-280.

Lenselink, G., Kroonenberg, S.B., Loison, G., 1990. Pleniglacial to Holocene paleo-environments in the Artière basin, in the western Limagne rift valley, Massif Central, France. Quaternaire 2, $139-156$.

Lepot, K., Benzerara, K., Brown Jr G.E., Philippot, P., 2008. Microbially influenced formation of 2,724-million-year-old stromatolites. Nature Geoscience 1, 118-121.

van Lith, Y., Warthmann, R., Vasconcelos, C., McKenzie, J.A., 2003. Microbial fossilization in carbonate sediments: a result of the bacterial involvement in dolomite precipitation. Sedimentology, 50, 237-245.

Lombardi, P., 1990. A rapid safe and convenient procedure for the preparation and use of diazomethane. Chemical Industry 5, 708. 
Lopez-Martinez, C., Grimalt, J. O., Hoogakker, B., Gruetzner, J., Vautravers, M. J., McCave I. N., 2006. Abrupt wind regime changes in the North Atlantic Ocean during the past 30,00060,000 years. Palaeooceanography 21, PA4215.

Macaire, J.-J., Fourmont, A., Argant, J., Bréheret, J.-G., Hinschberger, F., Trément, F., 2010. Quantitative analysis of climate vs human impact on sediment yield since the Late Glacial: the Sarliève paleolake catchment (France). The Holocene 20 (4), 497-516.

Maliński, E., Gąsiewicz, Witkowski, A., Szafranek, J., Pihlaja, K., Oksman, P., Wiinamäki, K., 2009. Biomarker features of sabkha-associated microbialites from the Zechstein Platy Dolomite (Upper Permian) of northern Poland. Palaeogeography, Palaeoclimatology, Palaeoecology 273, 92-101.

Marseille, F., Disnar, J.R, Guillet., B., Noack, Y., 1999. n-Alkanes and free fatty acids in humus and A1 horizons of soils under beech, spruce and grass in the Massif Central (Mont-Lozère) France. European Journal of Soil Science 50, 433-441.

McCarthy, R. A., Duthie, A.H., 1962. A rapid quantitative method for the separation of free fatty acids from lipids. Journal of Lipid Research 3, 117-119.

Mouradian, M., Panetta, R. J., de Vernal, A., Gélinas, Y., 2007. Dinosterols or dinocysts to estimate dinoflagellate contributions to marine sedimentary organic matter? Limnology and Oceanography 52, 2569-2581.

Pearson E. J, Farrimond P., Juggins S., 2007. Lipid geochemistry of lake sediments from semiarid Spain: Relationships with source inputs and environmental factors. Organic Geochemistry 38, 1169-1195.

Rashby. S. E., Sessions, A. L., Summons, R. E., Newman, D.K., 2007. Biosynthesis of 2methylbacteriohopanepolyols by an anoxygenic phototroph. Proceedings of the National Academy of Sciences 104, 15099-15104. 
Revsbech, N. P., Jørgensen, B. B., Blackburn, T. H., 1983. Microelectrode studies of the photosynthesis and $\mathrm{O}_{2}, \mathrm{H}_{2} \mathrm{~S}$, and $\mathrm{pH}$ profiles of a microbial mat. Limnology and Oceanography 28, 1062-1074.

Rohmer, M., Ourisson, G., 1976. Methyl-hopanes d'Acetobacter xylinum et d'Acetobacter rancens: une nouvelle famille de composes triterpéniques. Tetrahedron Letters 40, 3641-3644.

Rohmer, M., Bouvier-Nave, P., Ourisson, G., 1984. Distribution of hopanoid triterpenes in prokaryotes. Journal of General Microbiology 130, 1137-1150.

Rommerskirchen, F., Plader, A., Eglinton, G., Chikaraishi, Y., Rullkoötter, R., 2006. Chemotaxonomic significance of distribution and stable carbon isotopic composition of longchain alkanes and alkan-1-ols in C4 grass waxes. Organic Geochemistry 37, 1303-1332.

Rontani, J.-F., Volkman, J.K., 2005. Lipid characterization of coastal hypersaline cyanobacterial mats from the Camargue (France). Organic Geochemistry 36, 251-272.

Sadooni, F. N., Howari, F., El-Saiy, A., 2010. Microbial dolomites from carbonate-evaporites sediments of the coastal sabkha of Abu Dhabi and their exploration implication. Journal of Petroleum Geology 33, 289-298.

Sanchez-Roman, M., McKenzie, J.A., de Wagener Luca Rebello, A., Rivadeneyra, M.A., Vasconcelos, C., 2009. Presence of sulfate does not inhibit low-temperature dolomite precipitation. Earth and Planetary Science Letters 285, 131-139.

Sanz-Montero, M.E., Rodriguez-Arabda, J.P., Garcia del Cura, M.A., 2008. Dolomite-silica stromatolites in Miocene lacustrine deposits from the Duero Basin, Spain: the role of organotemplates in the precipitation of dolomite. Sedimentology 55, 729-750. 
Scherf, A.K., Rullkötter, J., 2009. Biogeochemistry of high salinity microbial mats - Part 1: Lipid composition of microbial mats across intertidal flats of Abu Dhabi, United Arab Emirates. Organic Geochemistry 40, 1018-1028.

Schopf, J.W., 2006. Fossil evidence of Archean life. Philosophical Transactions of the Royal Society B: Biological Sciences 361, 869-885.

Shiea, J., Brassell, S.C., Ward, D.M., 1990. Mid-chain branched mono- and dimethyl alkanes in hot spring cyanobacterial mats: a direct biogenic source for branched alkanes in ancient sediments? Organic Geochemistry 15, 223-231.

Simoneit, B.R.T., 1997. Compound-specific carbon isotope analyses of individual long-chain alkanes and alkanoic acids in Harmatten aerosols. Atmospheric Environment 31, 2225-2233.

Stefanova, M., Disnar, J.R., 2000. Composition and early diagenesis of fatty acids in lacustrine sediments, lake Aydat (France). Organic Geochemistry 31, 41-55.

Summons, R. E., Jahnke, L.L., 1992. Hopenes and hopanes methylated in ring-A: correlation of the hopanoids of extant methylotrophic bacteria with their fossil analogues. In: Biomarkers in Sediments and Petroleum (eds. Moldowan J.M., Albrecht P. \& Philp R. P.), Prentice Hall, NJ, pp.182-200.

Summons, R. E., Jahnke, L.L., Hope, J.M., Logan, G.A., 1999. 2-Methylhopanoids as biomarkers for oxygenic photosynthesis. Nature 400, 554-557.

Talbot, H.M., Summons, R.E., Jahnke, L.L., Cockell, C.S., Rohmer, M., Farrimond, P., 2008. Cyanobacterial bacteriohopanepolyol signatures from cultures and natural environmental settings. Organic Geochemistry 39, 232-263. 
Tomitani, A., Knoll, A.H., Cavanaugh, C.M, and Ohno, T., 2006. The evolutionary diversification of : Molecular-phylogenetic and paleontological perspectives. Proceedings of the National Academy of Sciences 103, 5442-5447.

Trichet, J., Défarge, C., 1995. Non-biologically supported organomineralization. Bulletin de l'Institut Océanographique (Monaco), Numéro Spécial 14, 203-236.

Vasconcelos, C., McKenzie, J.A., 1997. Microbial mediation of modern dolomite precipitation and diagenesis under anoxic conditions (Lagoa Vermelha, Rio de Janeiro, Brazil). Journal of Sedimentary Research, 67, 378-390.

Vilcheze C., Llopiz, P., Neunlist, S., Poralla, K., Rohmer, M., 1994. Prokaryotic triterpenoids: new hopanoids from the nitrogen-fixing bacteria Azotobacter vinelandii, Beijerinckia indica and Beijerinckia mobilis. Microbiology 140, 2749-2753.

Volkman, J. K., 1986. A review of sterol markers for marine and terrigenous organic matter. Organic Geochemistry 9, 83-99.

Warren J. 2000. Dolomite: occurrence, evolution and economically important associations. EarthScience reviews 52, 1-81.

Warthmann, R., Vasconcelos, C., Sass, H., McKenzie, J.A., 2005. Desulfovibrio brasiliensis sp. nov., a moderate halophilic sulfate-reducing bacterium from Lagoa Vermelha (Brazil) mediating dolomite formation. Extremophiles 9, 255-261.

Welander, P.V., Coleman, M. L., Sessions, A. L., Summons R. E., Newman, D.K., 2010. Identification of a methylase required for 2-methylhopanoid production and implications for the interpretation of sedimentary hopanes. Proceedings of the National Academy of Science 107 (19), 8537-8542. 
Westall, F., 2005. The geological context for the origin of life and the mineral signatures of fossil life. In "The Early Earth and the origin of Life", H. Martin, M. Gardaud, G. Reisse, B. Barbier (Eds), pp, 195-226. Springer, Berlin.

Wright, D., 1999. The role of sulphate-reducing bacteria and in dolomite formation.in distal ephemeral lakes of the Coorong region, South Australia. Sedimentary Geology, 126, 147-157.

Zenger, D.H., Dunham, J.D. and Ethington, R.L., 1980. Concepts and Models of Dolomitization. Society of Economic Paleontologists and Mineralogists, Tulsa, Oklahoma, 320 pp.

Zundel, M., Rohmer, M., 1985. Prokaryotic triterpenoids 3. The biosynthesis of $2 \beta$ methylhopanoids and 3 $\beta$-methylhopanoids of Methylobacterium organophilum and Acetobacter pasteurianus ssp. pasteurianus. European Journal of Biochemistry 150, 35-39. 


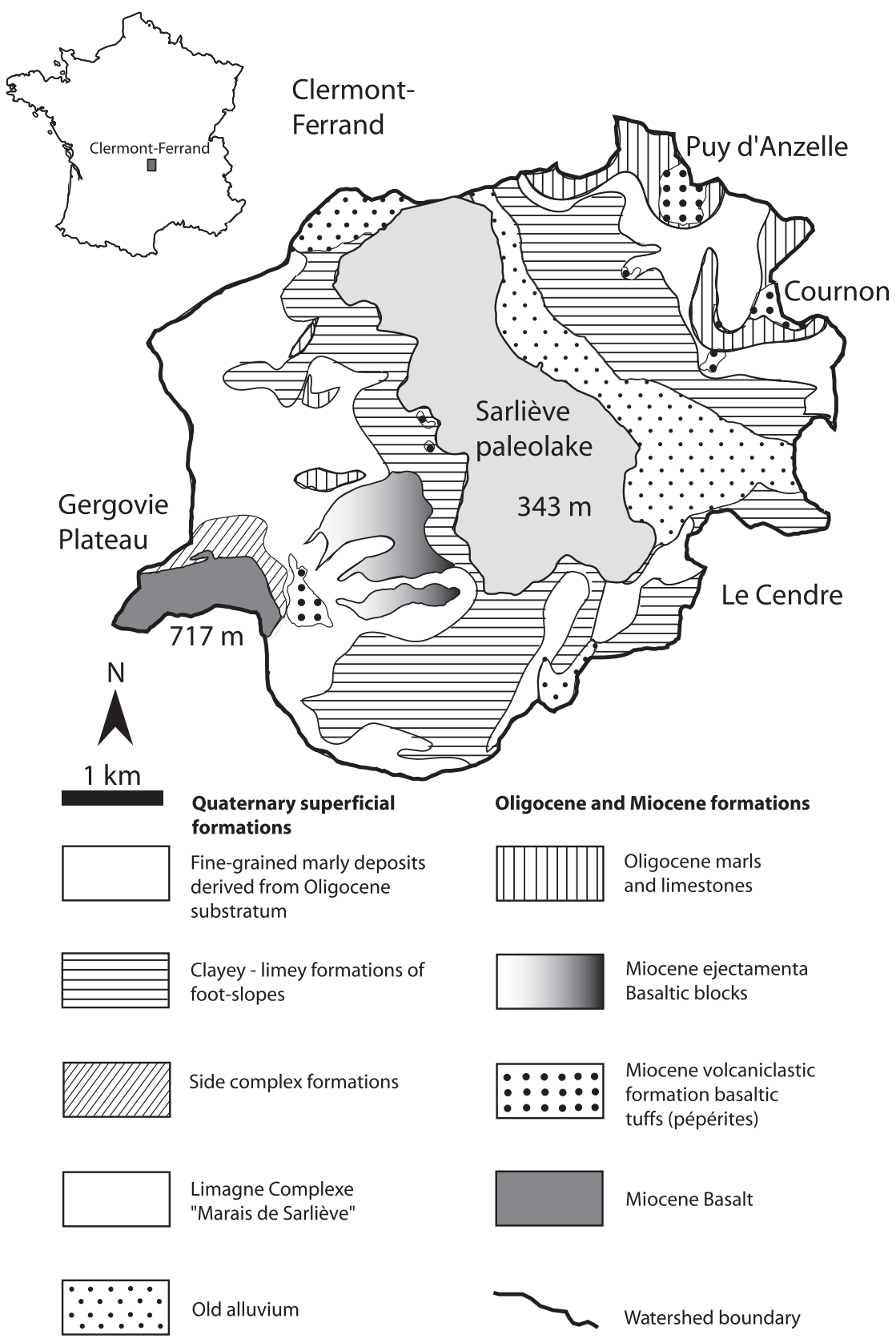

Figure 1 


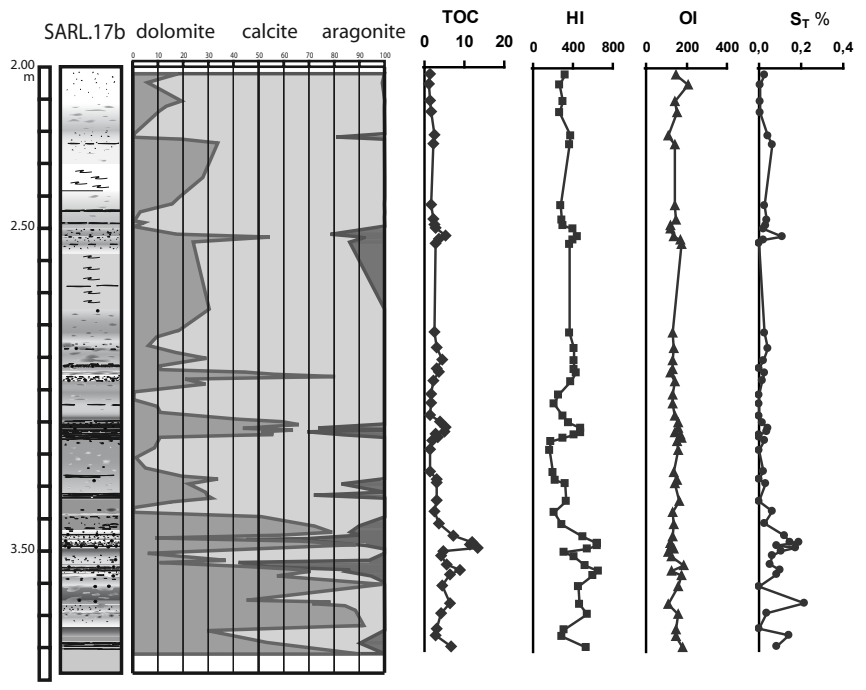

Fig. 2 


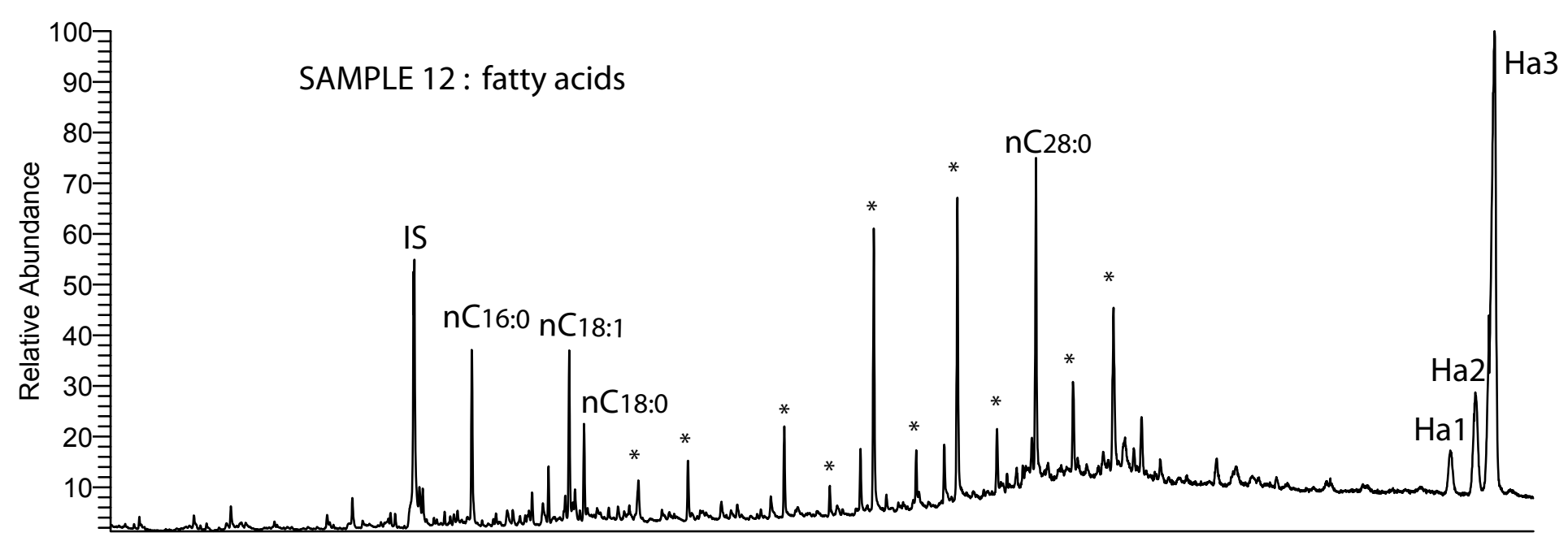

Fig. 3 


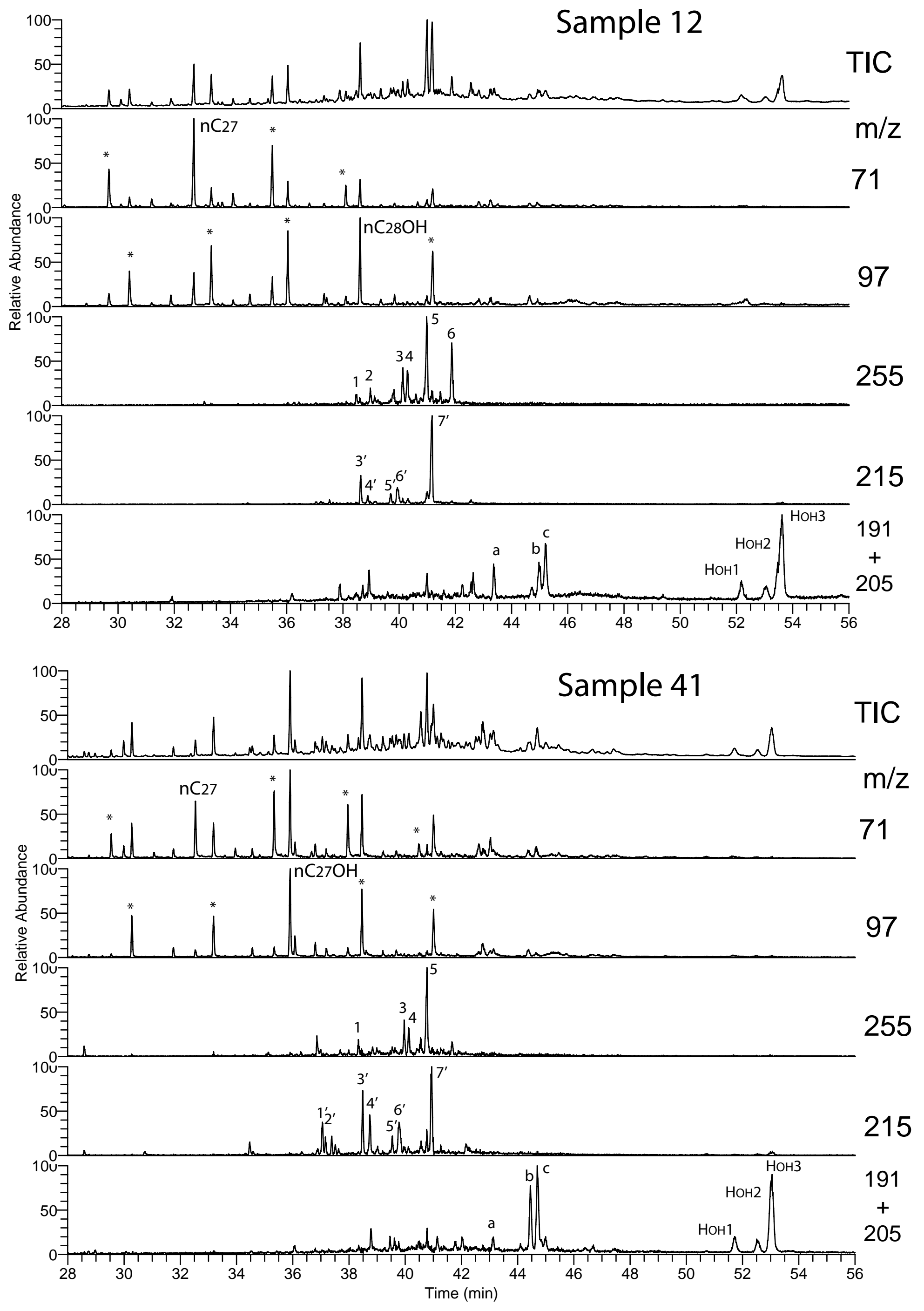


$\stackrel{1}{\stackrel{1}{12}}$
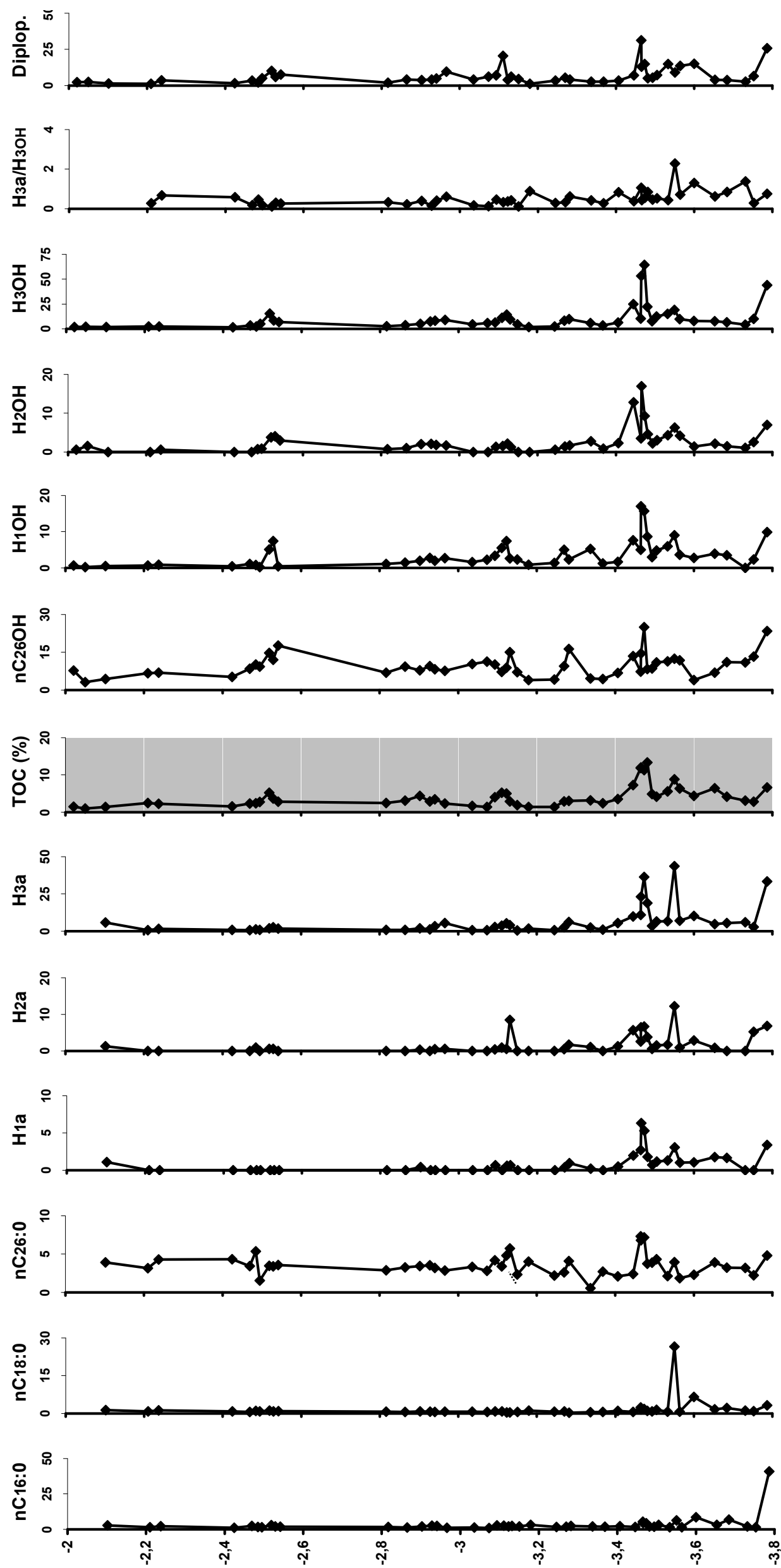

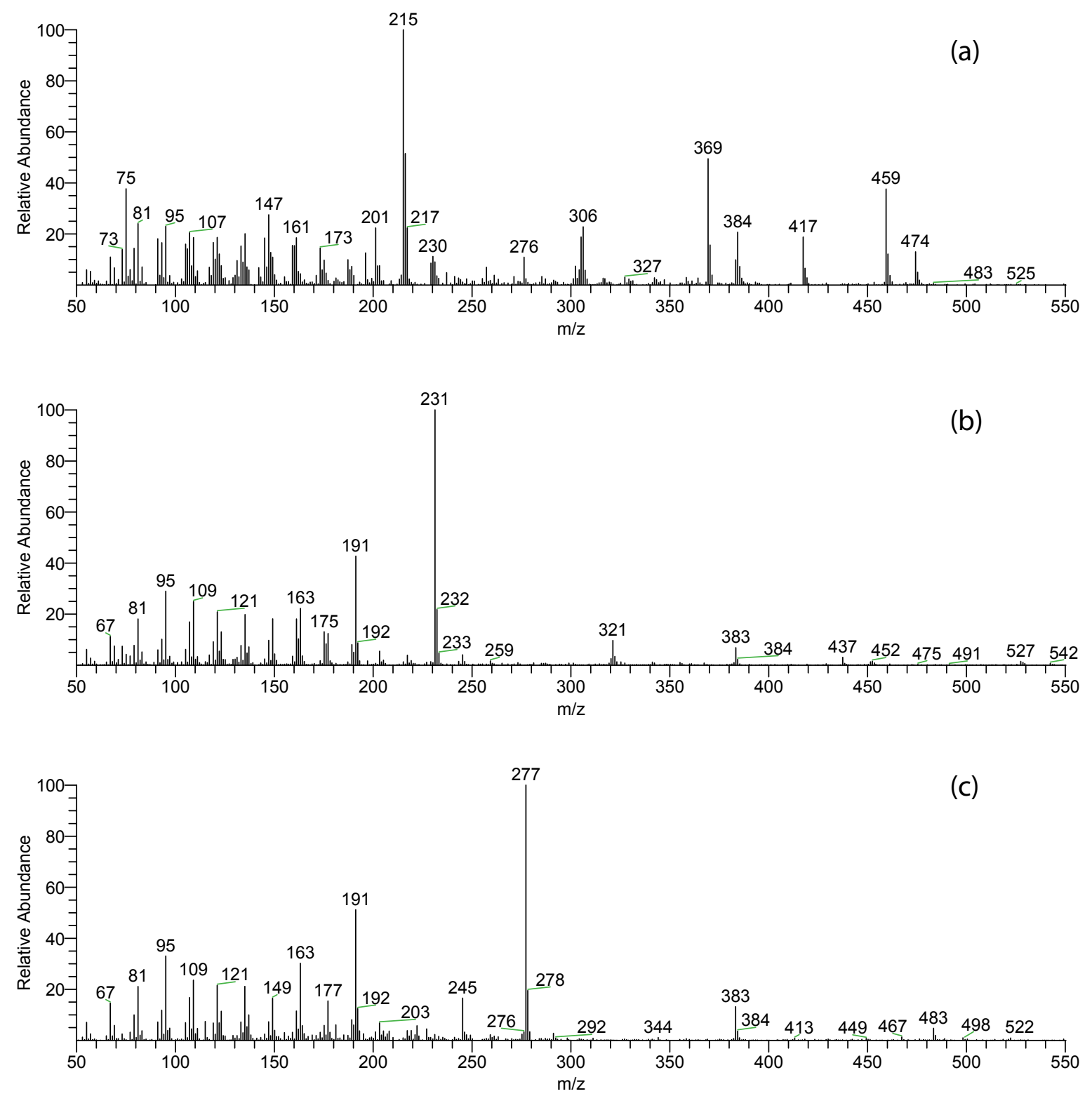